\title{
Video Media-Based Learning to Improve The Story Writing Ability of the 4th Graders of Public Elementary Schools in Cilacap Regency
}

\author{
Koko Gesang Ratoyo ${ }^{1}$, Winarno ${ }^{2}$, St. Y. Slamet ${ }^{3}$
}

\section{ARTICLE INFO}

Article History:

Received 03.03.2019

Received in revised form

18.10.2018

Accepted

Available online 01.12.2019

\begin{abstract}
This research aimed to design a video media-based learning to improve the writing ability of the 4th graders of Elementary School in Cilacap Regency. The procedure of development referred to educational research and development model. The output (product) was an interactive learning media in the form of learning CD that is usable to teachers in the class. The application in the learning showed that this learning model could improve writing ability with high category for experiment class, and with medium category only for control class. Teacher responded positively to this learning model as it could improve the students' ability. CD resulting from this development was equipped with children story and was organized systematically and in order. This learning media could be developed further into on-line learning. The development of video media-based children story writing learning model in Public Elementary Schools in Cilacap Regency. This research and development aimed to provide a children story writing learning model to improve writing ability. The procedure used included preliminary study, product development, expert validation, small-scale trial, and large-scale trial. The research and development had produced a video media-based children story writing learning model. This story writing learning model consisted of the stages of video media-based learning.
\end{abstract}

C IJERE. All rights reserved

Keywords:

Learning model, story writing, video media writing

\section{INTRODUCTION}

Model can be defined as a replica of actual object, thereby having shape or construction as same as or identical with the imitated object. In addition, the model can also be defined as conceptual or procedural example of a program, system, or process that can be reference or guideline in the attempt of solving a problem or achieving an objective (Sulisyorini, 2007: 13).

Learning model has four specific characteristics: (1) having logical theoretical rationale arranged by its creator or developer; (2) having rationale of what and how the students learn or the objective of learning to be achieved; (3) constituting a teaching action desirable to enable the model to be implemented successfully; and (4) needing learning environment in order to achieve the objective of learning (Trianto, 2015: 55).

A successful learning, according to Rahardjo and Daryanto (2012: 159), is highly determined by individual teachers' tricks in the class. It is because teachers play a role in the process of transforming knowledge and skill, and also in integrating all learning processes. Helmawati (2016: 147) revealed that learning model is a process affecting the students.

Considering the elaboration above, it can be concluded that learning model is a conceptual framework depicting a systematic procedure of organizing the learning experience to achieve certain objective and to function as guideline to learning designers and teachers in designing and implementing learning.

Media in teaching-learning process tend to be defined as graphic, photographic, or electronic tool to capture, to process, and to reorganize visual or verbal information. Education media is used in the attempt of communicating and interacting teachers and students in the learning process. Learning media can clarify message and information presentation, thereby can improve learning process and output (Mufarokah, 2009: 104).

Munir (2015: 18) revealed that video is a tool or media that can show off real object simulation. As a digital media showing a structure or a series of motion pictures, video can also be defined as a technology of capturing, recording, processing, storing, and changing the order of still motions, by presenting scenes in the movement electronically. Video is a motion picture. While object of animation is artificial one, the object of video is the real one.

Corresponding e-mail: ${ }^{1}$ kokogesangratoyo@gmail.com, Sebelas Maret University ,orcid.org/0000-0002-9247-1832

${ }^{2}$ winarno_uns@yahoo.co.id, Sebelas Maret University, https://orcid.org/0000-0001-7506-4250

${ }^{3}$ slametsty@yahoo.co.id, Sebelas Maret University, Indonesia. https://orcid.org/0000 -0002-9851-4733 
Video, according to Agnew and Kellerman (in Munir, 2015: 290), is a part of digital media showing a series of pictures or images giving illusion, picture, and fantasy in motion pictures. Video can also be said as the combination of still images read in order at a certain time and certain speed.

Video media is a series of devices that can project voiced-motion pictures. The combination of image and sound create the character as same as the original object (Sanaky, 2013: 119). Learning video media, according to Riyana (2007: 25), is a media presenting audio and visual contents containing learning messages including concept, principle, procedure, theory, and application of knowledge to help understand a learning material. Video is audio-visual learning material that can be used to deliver messages/lesson materials.

Learning video media, according to Arsyad (2004: 36), can be categorized into audio visual aids (AVA) type or media that can be watched and listened to. This media is usually stored in disk or tape. VCD media is a media with storing system and video recording system in which audio visual signal is recorded using plastic disk rather than magnetic tape.

Considering the elaboration above, it can be concluded that video media is one of audio-visual media types that can represent an object moving along with natural sound or appropriate sound. Video presents information, explains process, explains elaborate concept, teaches skill, shortens or extends time, and affects attitude.

Writing is not only depicting graphical symbols but also putting idea onto written language through sentences organized wholly, completely, and clearly, so that those ideas can be communicated successfully to readers. Therefore, in addition to mastering topic and problem to be written, the author is required to master other components like graphology, structure, vocabulary, fluency, and etc (Winarni and Slamet, 2014: $31)$.

Writing activity is a manifestation of ultimate language ability and skill mastered by students, following listening, speaking, and reading abilities. Compared with the other three abilities, writing ability is mastered more difficultly (Nurgiyantoro, 2010: 422)

Gie (1994: 17) argued that writing is synonym for composing. Composing is a series of an individual's activities of revealing and expressing idea in written language in order to be understandable to the readers. There four elements of composing: (1) idea, the topic or theme revealed in writing; (2) discourse, the manifestation of idea expression to be understandable to the readers; (3) organization, organizing and arranging the idea orderly by taking rule, principle, technique, and procedure into account; (4) medium, a means of delivering idea in written language related to vocabulary, grammar, and rhetoric.

Writing is an active language skill. Writing is an individual's peak ability to be called "skillful in using language". Writing is a very complex skill. It is because writing ability requires the mastery of many linguistic elements that will be the content of writing. Linguistic or message content element should be established in such a way thereby producing harmonious, coherent, and dense writing (composition) (Nurjamal, Sumirat, and Darwis, 2011: 4).

Celse-Murcia and Olshtain (in Mulyati and Tarmizi, 2009: 5.1) reveal that writing skill is the most difficult skill. Writing is an activity much more active than reading (Hayon, 2003: 93). In other words, writing is communicating and expressing others' thinking, feeling, and desire in written manner (Suriamiharja, Husen, Nurjanah, 1997:1). Furthermore, writing is to change oral language, may be copying or generating idea or feeling like composing, making mail, making report, and etc.

Writing skill is a language skill other than speaking, reading, and listening. Writing is a manifestation of communication method using media. Everyone has a talent to develop writing skill (Pamungkas, 2012: 57). It is in line with Zainurrahman (2013: 7-8) suggesting that writing skill has so broad and deep space to study, that should be mastered by an individual who wants to be a good writer. A writer's precision in using punctuation, language structure, diction, and type or font format mastery is important.

Writing, according to (1988: 60), is a growing process through many practices. As a process, writing is a series of activities occurring and involving some phases: pre-writing (preparation), writing (writing content development), and post-writing (review and revision of writing) needing many practices (Slamet, 2007: 97).Writing is a communicating activity, the delivery of written message (information) to others using written language as its media. Writing activity involves some elements: writer as message sender, content of writing, channel or media, and reader.

Writing is a creative process of putting idea into written language to inform, to convince, and to entertain. The result of creative process is usually called composition or writing. Despite different 
definitions, these two terms refer to the same product. The term 'writing' is often inherent to a typical creative process. Meanwhile, the term composing is often inherent to non-scientific creative process. Writing can be said as an activity of arranging letters into word or sentence to be conveyed to others, so that others can understand it. In this case, communication can occur well between writer and reader (Dalman, 2015:3-4).

Saddhono and Slamet (2014:151-152) argued that basically writing is not only generating idea or feeling but also revealing an individual's idea, knowledge, science, and life experience in written language. Therefore, writing is not a simple activity that should not be learnt, but it should be mastered. Writing, according to Kurniawan (2104:111), is an activity needing effort, thought, and time to express idea in human's mind.

Hastuti (1982:1) (in Saddhono and Slamet, 2014: 153) state that writing activity is a very complex activity, because it involves the regular way of thinking and many requirements related to writing technique: (1) the unity of ideas, (2) the use of clear and effective sentences, (3) paragraph arranged well, (4) the application of correct spelling norm, and (5) the mastery of adequate vocabularies.

\section{Situation of the Problem}

He problem in this research is focused on developing a video-based story writing model in the Elementary School of Cilacap Regency with the following sub-problems. How is the process and results of developing a learning model for writing stories based on video media that is valid and practical in improving the ability to write on story writing material for grade IV elementary schools in Cilacap Regency. What is the effectiveness of using video-based story writing models to improve the ability to write grade IV elementary school in Cilacap Regency.

\section{Aim of the Study}

The aim of this research and development in general is to produce a video-based story writing learning model for elementary schools in Cilacap Regency. The specific objectives of this research and development are to: (1) describe the process and results of developing a learning model for writing stories based on video media that is valid and practical in improving the ability to write on grade IV story writing material in Primary Schools in Cilacap Regency, (2) describe the conditions of learning by using a video-based story writing learning model for elementary schools in Cilacap Regency.

\section{METHOD}

The type of research used in this study was Research and Development (R\&D). Research and development is a strategy or research method considered as improving or dealing with learning practice efficaciously in the field. Research and Development (R\&D) is the method used to produce a certain product to test the product's effectiveness later (Sugiyono, 2013: 297). It is in line with Sukmadinata (2012: 164) explaining research and development as a process or procedure to develop the existing product. Furthermore, in this research, the procedure of development used referred to Sukmadinata's (2012: 57) research procedure involving the following stages: (1) preliminary study, (2) development through smallscale and large-scale trials, and (3) product model test through product trial.

\section{RESULT, DISCUSSION, AND SUGGESTIONS}

\section{Result}

The analysis is then followed with independent-t test to find out the effectiveness of video mediabased children story writing learning model product developed in improving the story writing ability in Indonesian language learning. Before conducting $\mathrm{t}$-test, prerequisite test was conducted first using normality and homogeneity tests. Meanwhile, the calculation of normality, homogeneity, and t-tests was conducted using SPSS program to anticipate the error of manual calculation and to obtain accurate result of test. The result of prerequisite and $\mathrm{t}$-tests is explained as follows.

\section{a. Normality Test}

Normality test is conducted to examine whether or not the two samples used are distributed normally. Meanwhile, the result of normality test calculation is explained as follows.

\section{1) Normality Test of Experiment Group}


The result of test on children's writing test ability in experiment group applying the video mediabased children's writing learning model in Indonesian language learning in writing subject matter can be seen in Table below.

Table. Result of Pretest and Posttest Normality Tests in Experiment Group using SPSS.

\begin{tabular}{ccccccc}
\hline $\begin{array}{c}\text { Experiment } \\
\text { group }\end{array}$ & $\begin{array}{c}\text { Type of } \\
\text { Test }\end{array}$ & Mean & $\boldsymbol{\alpha}$ & $\mathbf{D}_{\text {obs }}$ & Sig. & Note \\
\hline SD Negeri & Pretest & 54.68 & 0.05 & 0.146 & 0.179 & Normal \\
Sidaurip 01 & Posttest & 81.20 & 0.05 & 0.166 & 0.072 & Normal \\
\hline
\end{tabular}

From the table above showing the result of normality test using SPSS program in experiment class, it can be seen that pretest and posttest indicate normal condition. Such condition is indicated with $D_{\text {obs }}=0.146$ in pretest at significance level of 0.179 , and $\mathrm{D}_{\text {obs }}=0.166$ in posttest at significance level of 0.072 . The result of significance calculation in pretest and posttest values is higher than 0.05 as the required significance level. Thus, it can be said that $\mathrm{H}_{0}$ is supported; thus, considering the result of calculation using SPSS, it can be concluded that the result of pretest and posttest data in experiment class derive from normally distributed population.

\section{2) Normality Test of Control Group}

The test on the result of children writing story ability in control group applying direct learning model/learning model applied in Writing subject matter of Indonesian Language learning so far can be seen in Table below.

Table. Result of Pretest and Posttest Normality Test in Control Group using SPSS

\begin{tabular}{ccccccc}
\hline $\begin{array}{c}\text { Control } \\
\text { Group }\end{array}$ & $\begin{array}{c}\text { Type of } \\
\text { Test }\end{array}$ & Mean & $\boldsymbol{\alpha}$ & $\mathbf{D}_{\text {obs }}$ & Sig. & Note \\
\hline SD Negeri & Pretest & 53.07 & 0.05 & 0.154 & 0.068 & Normal \\
Tambakreja 02 & Posttest & 71.73 & 0.05 & 0.141 & 0.130 & Normal \\
\hline
\end{tabular}

From the table above showing the result of normality test using SPSS program in control group, it can be seen that pretest and posttest indicate normal condition. Such condition is indicated with $D_{\text {obs }}=0.154$ in pretest at significance level of 0.068 , and $\mathrm{D}_{\mathrm{obs}}=0.154$ in posttest at significance level of 0.130 . The result of significance calculation in pretest and posttest values is higher than 0.05 as the required significance level. Thus, it can be said that $\mathrm{H}_{0}$ is supported; thus, considering the result of calculation using SPSS, it can be concluded that the result of pretest and posttest data in control class derive from normally distributed population.

\section{b. Homogeneity Test}

Homogeneity test is used in this study to examine the similarity of two or more groups compared. Examining the similarity of two or more groups is very important for the next step, $t$-test. The test is conducted using SPSS program to anticipate the error of manual calculation, while the criterion of group to be considered as homogeneous is when significance is higher than the specified significance level, 0.05 . Considering the result of calculation using SPSS program, the following results are obtained.

\section{1) Homogeneity Test on Pretest Value}

The result of hypothesis test on pretest value of children story writing before using video mediabased children story writing learning model (in experiment group) and children's writing ability before using learning model usually used (direct learning model) can be seen in the following table.

Table. Result of Homogeneity Test on Pretest Value using SPSS

\begin{tabular}{|c|c|c|c|c|c|}
\hline Group & Mean & A & $\mathbf{W}_{\text {obs }}$ & Sig. & Note \\
\hline Experiment & 54.68 & & & & \\
\hline Control & 53.07 & 0.05 & 0.032 & 0.859 & eous \\
\hline
\end{tabular}


Considering the result of calculation using SPSS formula as shown in the table above, it can obtained $\mathrm{W}_{\text {obs }}=0.032$ at significance level of 0.859 , sig. $>\alpha 0.05$. The data of pretest value shows sig. $0.859>0.05$. The result of significance calculation on pretest value in experiment and control classes is higher than 0.05 as the specified significance. Thus, it can be said that $\mathrm{H}_{0}$ is supported, and it can be concluded that data of pretest value in experiment and control classes is homogeneous or the variance of both populations is homogeneous.

\section{2) Homogeneity Test on Posttest Value}

The result of hypothesis test on postest value of children story writing before using video mediabased children story writing learning model (in experiment group) and children's writing ability after using learning model usually used (direct learning model) can be seen in the following table.

Table 4.32 Result of Homogeneity Test on Posttest Value using SPSS

\begin{tabular}{cccccc}
\hline Group & Mean & $\boldsymbol{\alpha}$ & $\mathbf{W}_{\text {obs }}$ & Sig. & Note \\
\hline $\begin{array}{c}\text { Experiment } \\
\text { Control }\end{array}$ & 81.20 & 0.05 & 0.28 & 0.868 & $\begin{array}{c}\text { Homogen } \\
\text { eous }\end{array}$ \\
\hline
\end{tabular}

Considering the result of calculation using SPSS formula as shown in the table above, it can obtained $\mathrm{W}_{\mathrm{obs}}=0.28$ at significance level of 0.868 , sig. $>\alpha 0.05$. The data of posttest value shows sig. $0.868>0.05$. The result of significance calculation on pretest value in experiment and control classes is higher than 0.05 as the specified significance. Thus, it can be said that $\mathrm{H} 0$ is supported, and it can be concluded that data of posttest value in experiment and control classes is homogeneous or the variance of both populations is homogeneous.

\section{Equality Test}

Equality test aims to find out the prior ability of the two groups having similarity. Equality test in this stage is conducted with SPSS program help with independent t-test. Input data analyzed is pretest values of experiment and control classes that are compared later. The hypothesis of balance test is $\mathrm{H}_{0}=$ Control and experiment classes have equal prior abilities, while $\mathrm{H}_{1}=\mathrm{Control}$ and Experiment classes do not have equal prior abilities. The result of equality test using SPSS program is presented in Table 4.33 below.

Table 4.33 Result of Equality Test using SPSS

\begin{tabular}{ccccc}
\hline Group & Mean & $\mathbf{t}_{\mathbf{o b s}}$ & $\begin{array}{c}\text { Sig. } \\
\text { (2-tailed) }\end{array}$ & Notes \\
\hline $\begin{array}{c}\text { Pretest } \\
\text { Experiment }\end{array}$ & 54.68 & & & $\begin{array}{l}\text { Control and experiment } \\
\text { classes have equal prior } \\
\text { abilities. }\end{array}$
\end{tabular}

From the result of calculation using SPSS program as shown in table 4.33, it can be found $t_{\text {obs }}=-0.556$ at significance level of 0.580 , sig is higher than $\alpha$ or sig $>0.05$. Data of pretest value shows sig. $0.868>0.05$. The result of significance calculation on pretest value is higher than 0.05 as the required significance level. Thus, it can be said that $\mathrm{H}_{0}$ is supported. It can be concluded that the two classes, experiment and control classes have equal ability of writing children story.

\section{Effectiveness Test}

The calculation of $\mathrm{t}$-test in this study is conducted using independent $\mathrm{t}$-test, comparing two mean scores with different treatments against the unrelated samples. The result of independent $t$-test is presented in Table 4.33 .

Table 4.34 Result of independent t-test using SPSS

\begin{tabular}{ccccc}
\hline Group & Mean & $\mathbf{t}_{\text {obs }}$ & $\begin{array}{c}\text { Sig. } \\
\text { (2-taled) }\end{array}$ & Note \\
\hline Experiment & 81.20 & & & $\begin{array}{l}\text { The story writing learning using a } \\
\text { video media-based children story } \\
\text { writing learning model improves }\end{array}$ \\
\cline { 3 - 4 }
\end{tabular}


Table above shows the result of Independent Sample Test statistical analysis on the hypothesis formulation: $\mathrm{H}_{0}=$ Learning using direct learning model improve children story writing ability more effectively, and $\mathrm{H}_{1}=$ Learning using video media-based children story writing learning model improves children's writing ability more effectively.

From the result of analysis, it can be seen that the comparison of posttest values between experiment and control classes shows significant difference of children story writing ability between the two classes after attending the treatment. It is indicated with $t_{o b s}=-4.670$. This result of calculation $t_{o b s}$ is in fact at (2-tailed) significance level of 0.000 . Thus, $\mathrm{H}_{0}$ is not supported and $\mathrm{H}_{1}$ is supported, meaning that the learning using video media-based children story writing learning model is more effective.

\section{Discussion}

The research and development conducted has passed through three stages: preliminary study, product development, and product trial. Considering the problem statement, the objective of research is to find out process and product of a valid, practice, and effective video media-based children's writing learning model. The discussion on process and product of the development of a valid and practical video mediabased children story writing learning model is presented in sub chapter 1, while that on its effectiveness is presented in sub chapter 2 . The discussion of research result is elaborated as follows.

Process and Product of the development of a valid and practical video media-based children story writing learning model start with the result of preliminary study. Considering the activities in preliminary study involving interview, observation, distribution of teachers and students' need questionnaire, and document analysis, it can be found that students' ability of writing children story in Indonesian language learning is still low. In addition, teachers and students need varying Indonesian language learning model that can improve the children story writing ability.

In relation to writing ability, Musser et. al (2008: 6) states "Problem write is as much an art as it is a science. Therefore, you will find that with experience you will develop a feeling for when to use one strategy over another by recognizing certain clues, perhaps subconsciously". It means that writing is just like art as it is a science, the way of finding it is through experience that will develop feeling during using one strategy over another by recognizing certain clues, perhaps subconsciously. Considering this definition, writing ability is the use of one strategy over another with certain clues. It of course makes the students needing more thinking process to write.

Writing ability is very desirable today to address the educational challenge in $21^{\text {st }}$ century. Writing ability, according to Directorate General of Primary and Secondary Education, is one of students' competencies to be built and developed. Furthermore, Indonesian language as one of subject contributes to developing students' writing ability. In Indonesian language learning, some difficult materials are studied difficultly by students at elementary school. The difficulty can be seen from les meaningful learning activity the teachers have conducted. The importance of writing material mastery is not only limited to Indonesian language lesson, but it also uses writing concept in such disciplines as biology, physics, chemistry, engineering, economics, and psychology. Therefore, students should understand and master in-depth the writing material learning in elementary school.

Learning model applied by teachers in delivering material related to writing ability should encourage the students to participate actively in the learning, so that the communication is established not only in one way from teachers to students but also from students to teacher, between students and students, and between students and learning source used. Learning model, according to Suprijono (2014: 46), is a conceptual framework depicting a systematic procedure of organizing learning experience to achieve the objective of learning. Many innovations have been taken to improve the story writing ability. It can be seen from some researches studying the story writing ability learning and varying learning models. The selection of learning model integrated into approach in this study can also address the need for learning model compatible to the characteristic of Indonesian language learning, particularly to improve the story writing 
ability. The learning model developed not only emphasizes on thee end result of learning, but also paying attention to the learning process occurring.

Furthermore, Sanjaya (2010: 241) states that writing learning model is a series of learning activities conducted by students to achieve the objective of learning. Story writing learning is a manifestation of concept and technique to help maximize the students' writing ability. The advantage of current research is, among others, that it creates positive cooperation in building their own knowledge among individual students. The integration of video media-based children story writing model results in a learning process easy to be followed by students. This learning model has specific characteristic in its implementation, namely practicing the children to write story. The students' active participation in the learning process will give the students an opportunity of sharpening their ideas and therefore, teachers will recognize the students' possibly wrong idea and they can correct the error (Isjoni, 2009: 87). The objective of research is to improve the children story writing ability. The result of research shows an improvement in students' ability of writing children story.

The learning procedure existing in the video media-based children story writing learning model are expressed in 5Ms (Mengamati [observing], Menanya [questioning], Mengumpulkan Informasi [gathering information], Mengasosiasi [associating], and Mengomunikasikan [communicating]) activities.

This development of video media-based children story writing considers the basic elements of learning model. Joyce \& Weil in Sumantri (2015: 37) mentions that learning model has five basic elements: 1) syntax, 2) social system, 3) reaction principle, 4) supporting system, and 5) instructional and accompanying effects. This learning model development meets the five elements, as indicated with the product of model development stage. The model development stage shows that this model is valid and practical to apply to Indonesian language learning.

The validity of learning model development can be seen from the result of validation on syntax 3.85, RPP of 3.74, teaching material of 3.85, and worksheet of 3.82. The result of validation on learning set developed based on scale 1-4 belongs to very good category, so that it can be said that the product of learning model development is valid. Meanwhile, the practicality aspect of learning model developed can be seen from the result of learning model practicability questionnaire. In small-scale trial stage, the model's practicability score is 4.07. Similarly, in large-scale trial conducted in two elementary schools, the result of learning model's practicability questionnaire shows mean score of 4.02 and 4.20,. Considering the result of learning model's practicability questionnaire, the learning model developed belongs to very good category (scale 1-5). Thus, practicality aspect is fulfilled in the learning model developed.

Having passed through development stages, a feasible an effective vide media-based children writing learning model is produced to be used in story writing material of Indonesian language learning activity. The measurement of learning model's effectiveness is implemented after small- and large-scale trials have been completed. The effectiveness test was conducted in the $4^{\text {th }}$ grades of SDN Sidamulya 01 ( $1^{\text {st }}$ Public Elementary School of Sidamulya) and SDN Pahonjean 01 (1 $1^{\text {st }}$ Public Elementary School of Pahonjean). Furthermore, SDN Binangun 01 (1 $1^{\text {st }}$ Public Elementary School of Binangun) was determined as experiment class with 25 students and SDN Tambakreja 02 ( $2^{\text {nd }}$ Public Elementary School of Tambakreja) as control class with 30 students.

Effectiveness test aims to find out whether or not the learning model developed is effective, viewed from the children story writing ability. Effectiveness test need pretest and posttest values. Pretest value is used to find out the students' prior ability before using learning model developed, while posttest value is used to find out the students' ability after the use of learning model developed.

This research conducted in Cilacap Regency departs from Slavin's (2008: 218) recommendation stating that the procedure in the syntax of story writing learning contains some stages: choosing sub theme in group, planning investigation, implementing, planning presentation, presentation, and evaluation that can encourage the students to construct their own knowledge (Slavin, 2008: 218).

Considering the findings of some previous studies, the similar findings are obtained in this study. The result of effectiveness test using independent t-test shows that the score of children story writing ability using the video-media-based children story writing learning model is higher than that using learning model. It can be seen from the result of $\mathrm{t}$-test analysis showing $\mathrm{t}_{\mathrm{obs}}=-4.670<\mathrm{t}_{\text {tabel }}=2.004$; thus it can be concluded that $\mathrm{H}_{0}$ is not supported. It means that the video media-based children story writing learning model can 
improve the children writing ability. The result of $\mathrm{t}$-test proves that the product of video media-based children story writing learning model developed improves the children story writing ability.

Considering the result of effectiveness test, the research problem concerning the effectiveness of video media-based children story writing learning model developed has been answered. It can be seen from the class applying the learning model developed with children story writing ability better than the one applying direct (conventional) learning model.

\section{Suggestions}

The effectiveness of Video Media-Based Children Story Writing Learning model is based on whether or not the increase in the students' writing ability level in Indonesia language learning in experiment class using Video Media-Based Children Story Writing Learning model, compared with the control class using conventional learning model. Considering this finding, it can be concluded that the use of Video MediaBased Children Story Writing Learning model effectively improves the students' writing ability in story writing material of Indonesian learning in the $4^{\text {th }}$ grade of Elementary School.

\section{REFERENCES}

Arsyad,A.(2004). Media pembelajaran. Jakarta: PT. Raja Grafindo Persada.

Dalman (2015). Ketrampilan menulis. Jakarta: PT. Raja Grafindo Persada.

Helmawati (2016). Pendidik sebagai model. Bandung : Remaja Rosdakaya

Kurniawan, H.(2014). Pembelajaran menulis kreatif. Bandung: Remaja Rosdakarya.

Mufarokah, A. (2009). Strategi belajar mengajar. Yogyakarta: Teras.

Mulyati,Y.(2009). Ketrampilan Berbahasa Indonesia SD. Jakarta: Universitas Terbuka

Nurgiyanto, B. (2010). Penilaian Pembelajaran Bahasa Berbasis Kompetensi. Yogyakarta: BPFE.

Nurjamal, W. (2011). Terampil Berbahasa. Bandung: Alfabeta.

Pamungkas, S. (2012). Bahasa Indonesia dalam Perspektif. Yogyakarta: Andi

Rahardjo, M.(2012). Model Pembelajaran Inovatif. Yogyakarta: Gava Media.

Riyana, C. (2007). Pedoman Pengembangan Media Video. Jakarta: P3AI UPI.

Saddhono, K \& Slamet, St, Y. (2014). Pembelajaran Ketrampilan Berbahasa Indonesia. Yogyakarta: Graha Ilmu.

Slamet, St, Y. (2008). Dasar-dasar Ketrampilan Berbahasa Indonesia. Surakarta: LPP UNS dan UNS Press.

Sukmadinata, N. S. (2012). Metode Penelitian Pendidikan. Bandung: PT Remaja Rosdakarya.

Sulisyorini, S.(2007). Model Pembelajaran IPA Sekolah Dasar. Semarang: Fakultas Ilmu Pendidikan, Jurusan Pendidikan Guru Sekolah Dasar Universitas Negeri Semarang (UNNES) dengan Tiara Wacana.

Suriamamihardja, A. H.(1997). Petunjuk Praktis Menulis. Jakarta: Dirjen Dikti Depdikbud.

Trianto (2010). Model Pembelajaran Terpadu Konsep, Strategi, dan Implementasinya dalam Kurikulum Tingkat Satuan Pendidikan. Jakarta: Bumi Aksara.

Winarni, R. \& Slamet, St, Y. (2014). Menulis Cerita. Surakarta: UNS Press.

Zainurrahman (2013). Menulis dari Teori Hingga Praktik. Bandung: Alfabeta. 